CORRECTION

\title{
Correction: Divergence of a genomic island leads to the evolution of melanization in a halophyte root fungus
}

Zhilin Yuan (D), Irina S. Druzhinina, John G. Gibbons (D), Zhenhui Zhong (D), Yves Van de Peer, Russell J. Rodriguez, Zhongjian Liu (D), Xinyu Wang (D), Huanshen Wei (iD, Qi Wu, Jieyu Wang, Guohui Shi (D), Feng Cai (D), Long Peng (iD) and Francis M. Martin (iD)

(c) The Author(s) 2021

The ISME Journal (2022) 16:321; https://doi.org/10.1038/s41396-021-01083-w

Correction to: The ISME Journal https://doi.org/10.1038/s41396021-01023-8.

The original version of this article, unfortunately, contained a mistake in the affiliation of Prof. Yves Van de Peer:

${ }^{7}$ Department of Plant Biotechnology and Bioinformatics, Ghent University, Ghent, Belgium

${ }^{8}$ VIB Center for Plant Systems Biology, Ghent, Belgium

${ }^{9}$ Centre for Microbial Ecology and Genomics, Department of Biochemistry, Genetics and Microbiology, University of Pretoria, Hatfield, South Africa

The original article has been corrected.

\begin{abstract}
(c) Open Access This article is licensed under a Creative Commons Attribution 4.0 International License, which permits use, sharing, adaptation, distribution and reproduction in any medium or format, as long as you give appropriate credit to the original author(s) and the source, provide a link to the Creative Commons license, and indicate if changes were made. The images or other third party material in this article are included in the article's Creative Commons license, unless indicated otherwise in a credit line to the material. If material is not included in the article's Creative Commons license and your intended use is not permitted by statutory regulation or exceeds the permitted use, you will need to obtain permission directly from the copyright holder. To view a copy of this license, visit http://creativecommons. org/licenses/by/4.0/.
\end{abstract}

(c) The Author(s) 2021 